\title{
Educational Games In Physical Education To Increase Self-Confidence Children With Special
}

\author{
Tri Rafi Harma ${ }^{1}$, Eddy Marheni ${ }^{2}$, Eko Purnomo ${ }^{3}$ \\ ${ }^{1}$ Universitas Negeri Padang, Padang, Indonesia (trirafiharma310398@gmail.com) \\ ${ }^{2}$ Universitas Negeri Padang, Padang, Indonesia (eddymarheni@fik.unp.ac.id) \\ ${ }^{3}$ Universitas Negeri Padang, Padang, Indonesia (ekopurnomo@ fik.unp.ac.id)
}

\begin{abstract}
This research is based on the problem of trust in children with special needs. Learning development methods are not only in the classroom, can also be done outside the classroom. The purpose of this study is to provide solutions in solving problems of more effective learning planning systems in educational games in the field. This research was conducted on August 3 - September 28, 2018 at the Perwari Padang, Perwari. The focus of the research is on game modification learning that has been conducted at Padang Perwari school. This type of research is qualitative research with the observation method, the education educative game program, and documentation. The main object in this study is students with special needs in Padang Perwari. The results of research on good social interaction, the emergence of cooperation in completing a game, and the growth of confidence in interacting with friends in completing physical activities.
\end{abstract}

Keyword: Self-confidence, Special Schools, Children with special needs.

\section{Preliminary}

Education is learning knowledge, skill, and the habits of a group of people who are passed down from generation to generation through teaching, training, or research. Education often occurs under the guidance of others, but also allows self-taught. Education is a conscious effort to influence students to be able to develop and actualize the potential potential possessed in order to be able to live life as well as possible. The potential that exists within each student is positive or in the form of education (Bandi Utama, 2011). In the development of this process can take place in a family environment, school, and society. Understanding education in the national education system is an attempt to prepare students through the teaching and learning process (Gurit Prastowo dan Abdul Rachman Syam. 2014). This means that education can be done without knowing the age limit, space and time. In the 1945 Constitution article 31 paragraph 1 which states"that every citizen has the right to get education" (Yuniar Indahutari dan nanik indahwati, 2015). this verse sounds in line with the concept of education for all (education for all) which is affirmed in the universal declaration of Human Rights. 
Character is a behavior that is shown by someone in daily life who has a tendency towards positive or negative. Then it develops the notion of character which is defined as a special sign or pattern of behavior (Bohlin, Farmer, \& Ryan, 2001). The term character comes from the Greek "charassein" which means to carve. (Elmubarok . 2008) mention that character building is the process of carving or carving souls in such a way, so it is unique, interesting, and different or can be distinguished from others, like a letter in the alphabeta that is never the same as one another. so people with character can be distinguished from one another, a person with a commendable character can be distinguished from the others (Lickona 1991:50). Forming a likened character is like carving on a gemstone or a hard iron surface. Character is a special personality that is the driving force and driving force, and what distinguishes it from other individuals (Furqon. 2010). This character education aims to be able to shape the character / personality of the nation's children in accordance with the Law Number 14 of 2005 concerning the National Education System (sisdiknas) article 3 which is faithful and devoted to the Almighty God, noble, competent, creative, independent and become a democratic citizen and responsibility. (Lickona. 1991) states that character education is a deliberate effort to help someone so that he can understand, pay attention, and carry out core ethical values. Characters are shaped by good habits and are also shaped by the environment and education that researchers get.

Self-confidenceis a positive attitude of an individual who convinces himself to complete something he will do and develop positive values both for himself and for the environment / situation he faces. (Horn. 2008) defines confidence as a belief that someone has internal resources, especially ability. Selfconfidence is a personality trait that implies the belief in one's own abilities, so that individuals are not easily influenced by others (Lautser. 20013). to achieve success, that is, confidence is rooted in faith and hope. Self-confidence is an absolute personality aspect that every individual must possess because it relates to confidence "I can". Whereas according to (Al-uqshari. 2005) confidence in a form of strong belief in the soul, understanding with the soul, dan ability to master the soul.

The child with special needed are children with special characteristics that are different from children in general without always showing mental disability, emotional or physical. Based on this understanding, children who are categorized as having physical aspects include abnormalities in the sense of sight (blind), hearing sensory abnormalities (deaf), speech impairment, (speech impaired) and limb function abnormalities (disabled) (Nandiyah Abdullah. 2013). The term "special needs" is explicitly aimed at children who are considered to have abnormalities / deviations from the average condition of normal children generally, in physical terms, mental and social behavior characteristics (Efendi. 2006). Children with special needs include children with disabilities namely students who experience significant deviations or differences from the condition of people in general (average), so students need special educational services so 
that students can develop their potential optimally. These deviations can occur in the physical, mental aspects, social and or emotional (Lilik Maftuhatin, 2014).

An extraordinary school is one of the educational institutions with the aim to fulfill national education goals as well as to explore the abilities of students with optimal special needs (Fatah dan Yusuf. 2015). the government affirms that every citizen has the right to education. Di Indonesia pendidikan bagi anak yang memiliki keterbatasan telah diamanatkan dalam RI Law No. 20 of 2003 concerning the Implementation of Special Education for Students. Special education is education for students who have difficulty in following the learning process due to physical abnormalities, emotional, mentally, social, and/or has special intelligence and talent potential (pasal 127).

The function of the game in improving child growth and development is very good. Play has an important role in human life that can be seen from the psychological aspect, physical, and social. through play there will be positive changes in physical matters, social, mentally, and moral (Sukintaka, 1998). Some components of the psychological aspects will develop through play among others in terms of intelligence, motivation, emotion, mentally, confidence, interest, will, worry, aggressiveness, attention, concentration, etc (Bandi Utama, 2011). Physical aspects will also develop well through playing activities, includes physical growth and development, physical fitness, physical health, basic motion capability, existing physical elements. Even social aspects will develop well through this playing activity between in terms of cooperation, communication, mutual trust, respect, community, tolerance, togetherness and so on.

Children who are confident will have characteristics, among others: more independent, not too dependent on people, able to assume the responsibility given, can respect yourself and his own business, not easily experience frustration, able to accept new challenges or tasks, have more vibrant emotions but remain stable, easy to communicate and help others (Inge Pudjiastuti Adywibowo. 2010). According to Eko Sugiarto (2009), the characteristics of a shy child (inferiority) what researchers can observe is: often avoid eye contact (looking down / throwing the other direction), often go berserk to release anxiety, not much to say (often answer enough when asked, as: "yes" or "no", even just nodding or shaking his head), do not want to follow activities in class or outside class (passive), do not want to ask for help or ask people who are not well known, experience stage fright at certain times, for example when asked to come to the front of the class, it's difficult to blend in with the new environment / situation (it takes a long time to adjust).

Based on the results of observations made at the extraordinary school of Perwari Padang researchers identified the difficulty of students doing a physical movement that resulted in a lack of confidence in children with special needs. things that make researchers interested in doing research on Educational Games in Physical Education to Increase Self-Confidence of Children with Special Needs in Padang Special School Perwari. The aim of the researcher is to find 
out the level of confidence that children with special needs have in Padang Perwari Special School.

\section{RESEARCH METHODOLOGY}

The type of research used in this study is qualitative research, with data collection methods using interviews and observations. This research was conducted on 2 August - 29 September 2018 at Padang Perwari Special School, Sumatera Barat. In addition the application process, researchers lined up children with special needs in advance to give direction regarding the implementation of the game to be carried out. After the children line up neatly, the researcher exemplifies or demonstrates the game that the researcher has made, by passing various obstacles from star to finish well, After giving directions about the correct game, the researcher gives the opportunity for the child to play games alternately with his friends. Subjects in this study amounted to 20 students who were children with special needs in the extraordinary school Perwari Padang. The data collection techniques and tools use observation, interview and documentation methods. Data analysis techniques in this study are more of a description of the results of observations, interviews and documentation. Data that has been obtained qualitatively and described in descriptive form (Patton, 2001:103). The data analysis technique used in this study is to use steps like those proposed by (Burhan Bungin 2003:70), namely as follows:

1. data collection

2. data reduction

3. Data display

4. Conclution drawing and verification

Research Instruments:

The research instrument is to use educational game methods in the form of physical education. The form of the game is to bring and then enter the ball through the obstacle obstacles that have been prepared. Materials or tools to make these obstacles are:

1. Rainbow carton.

2. Used cardboard.

3. Used shoelaces.

4. 1 piece of used shoe box.

5. Small plastic balls with 3 kinds of colors totaling 20 pieces.

6. 10 pieces of $600 \mathrm{ml}$ mineral plastic bottles and 5 pieces of $1000 \mathrm{ml} / 1$ liter plastic bottles, used bottles are used mineral plastic bottles

7. Ravia rope.

8. One piece of water paralon 1.5 meter long, the water used is paralon of used water.

9. Bench that has the same size 2 pieces.

10. 1 piece of used ceramics

11. And 3 pieces of plastic waste baskets are cleaned, this basket is adjusted to 3 different colors of the ball. 
Bring together ingredients:

1. Make a necklace from rainbow cardboard and used cardboard with a star shape, then glue it with a used shoe string to resemble a star necklace

2. Enter the 20 colored balls into the shoe box.

3. Fill all mineral bottles with water

4. Prepare $10600 \mathrm{ml}$ bottles, then cut a 1 meter raffia rope with both ends of the rope tied to the mineral bottle head, one end of the rope uses one bottle of mineral, then in one meter the rope consists of 2 bottles of mineral.

5. Place the paralon above the back of the chair.

Arrange the game:

1. Place the box containing the ball near the star line

2. Arrange the $600 \mathrm{ml}$ bottle that has been tied together with a distance of 1 meter each, the rope must be tense to be jumped.

3. Arrange the $1000 \mathrm{ml} / 1$ liter mineral bottle straight towards the finish line, to be able to do a zik zak move.

4. After that, place the chair with paralon above the backrest, resembles a cave to be passed below.

5. Put the used ceramic as a support board, for the place to throw the ball into the basket.

6. Arrange the basket to widen at the same distance.

Examples of game forms:

1. Use a star necklace.

2. Take the ball in the box.

3. Jump over the rope that has been tied to the mineral bottle.

4. Move the zik-zak through plastic bottles.

5. Pass the chair and paralon underneath.

6. Stand with both feet on the pedestal ceramic.

7. Insert the ball into the basket, the color of the ball that is inserted must match the color of the basket.

8. Run towards the star line.

9. Give a star necklace to a friend who will do the next.

10. That's how it goes until all students finish doing it. 
Picture 1. Desain Educational Games.

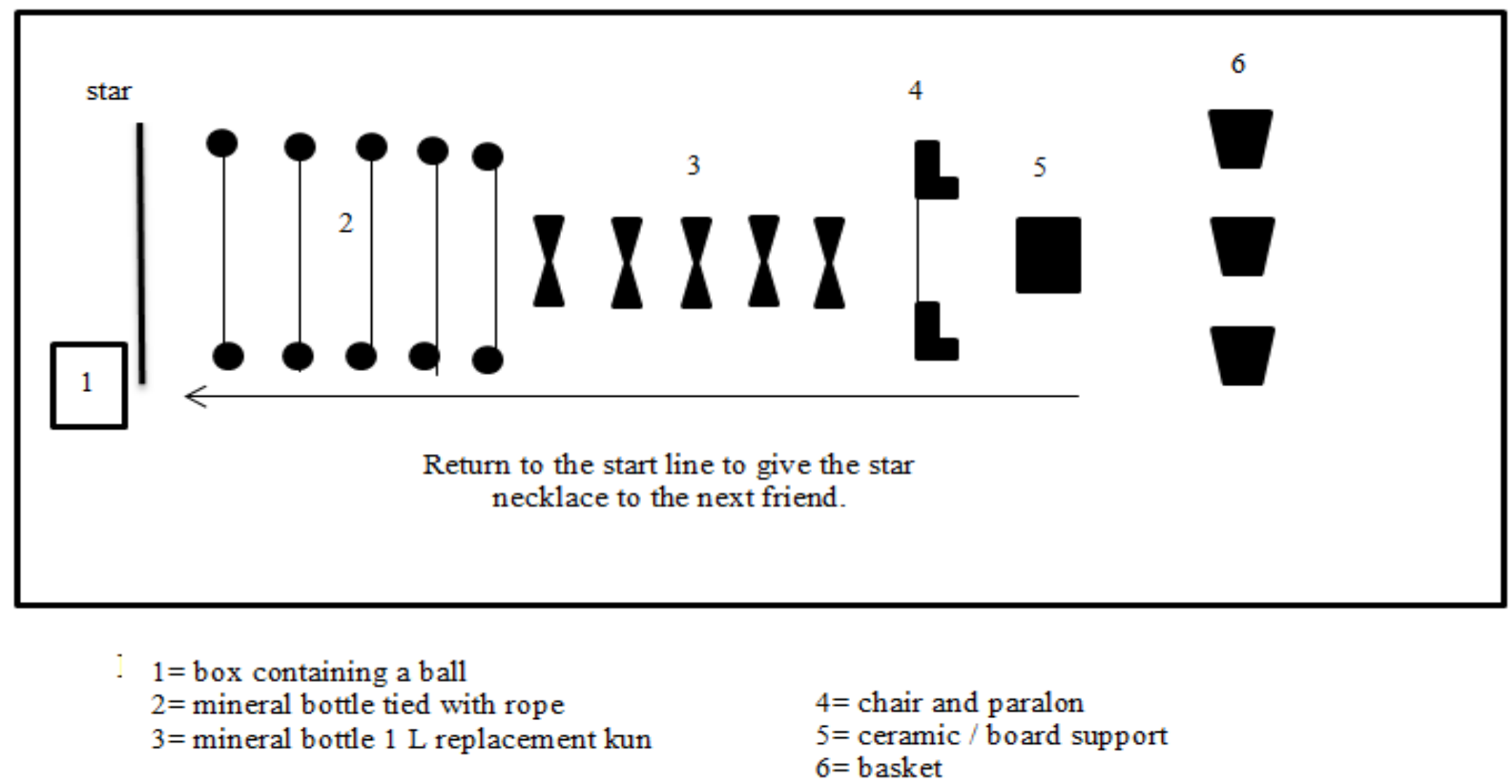

\section{RESULTS AND DISCUSSION \\ Result and Discussion}

From the results of research conducted by researchers found a problem of confidence when playing a game, the difficulty of students in carrying out physical activities creates problems in students' emotions which results in the emergence of a lack of confidence in children. During the game there are some children who have very little confidence, at that time the teacher at the school helped support or convince the child to do it. Providing motivation and support makes shy children who ultimately want to do it, even though when playing a game there is a problem with the gross motor, but thanks to the motivation and support of the environment that made him believe and believe in completing or completing the game, this proves that playing is not only a physical aspect that develops but also social, This agreed with Sukintaka (1998) which states that through playing there will be positive changes in physical matters, social, mental, and moral.

Researchers also concluded that through playing children can channel or release energy and emotions that have been latent which makes turmoil in students' self-confidence, when playing children various kinds of happiness like shouting, running around, circling and others. Hurlock (1978:323) stated about the influence of playing in the world of children, that play has to do with child development, these influences include: the urge to communicate, channeling to pent-up emotional energy, Learning Resources, self-insight development, community learning, moral standards. 


\section{A. Encouragement to Communicate}

Through play activity encourages children to learn to build communication between children so that a form of activity occurs (Moeslichatoen, 1999:32). Communication is important for science (Mery Noviyanti. 2011). In the game made by researchers there is an element of cooperation, giving a necklace to a friend supports communication in collaboration while playing.

\section{B. Distribution for Hidden Emotional Energy}

Playing will satisfy the demands of motoric development needs, cognitive / creativity, language, social, values and attitudes of life (Moeslichatoen, 1999:32). Playing is a medium for channeling potential tensions or energy caused by environmental restrictions on students' life behavior (Hurlock. 1978:323). In the game given by child researchers can realize the energy and emotion that students have been inclined to because it is difficult to reach a physical activity, by modifying a game that is easy to achieve and that he never met made the students happy and released the elements of energy and emotion that were controlled in the game media that the researchers gave.

\section{Learning Resources}

Playing provides a wide opportunity for children to learn various fields that are not obtained through studying at school, family and community (Moeslichatoen, 1999:32). Playing is a learning experience that is very useful for children, some of the benefits of playing include (Tedjasaputra, 2001:30-45); (1) For the development of physical aspects, (2) For the development of gross motor and fine motor aspects, (3) For the development of social aspects, (4) For the development of emotional or personality aspects, (5) For the development of cognitive aspects, (6) To sharpen sensing sharpness, (7) To develop sports and dance skills. From the game that the researcher gave researchers, it was concluded that through children's play learning to interact, get to know an object, solve a moving circuit, and learning to socialize in communicating.

\section{Development of Self-Insight}

Playing is a mirror in children's lives. Through play the child is able to see himself because there are benchmarks or comparisons that are friends or opponents playing, so students know their strengths and weaknesses in various fields such as physical, psikis, dan social (Moeslichatoen, 1999:32). The mental values contained in play activities are as follows; (a) children become aware of their rights and learn to respect others, (b) trust each other among playmates, (c) recognize self deficiencies, when compared to others. Added with children also recognizes the strengths of others and controls the emotions of excessive movement (Nurhayati Simatupang. 2005). Through play activities provided by the child researcher will learn in the community by communicating with his friends, with the teacher, and with researchers, learn to respect to take turns waiting to play, learn to obey the rules of the game that the researcher has set in the game, togetherness and cooperation in playing games. 


\section{E. Community Learning}

Playing can also be interpreted as the center of "community" activities for children. In social life there is certainly communication, social relations, value of cooperation, helping each other, there are rules that must be obeyed, there is a common goal to be achieved, mutual respect, mutual trust, ada rasa senang, love, togetherness, harmony, and peace. (Moeslichatoen, 1999:32). The benefits of playing in terms of social aspects will increase the relationship, add familiarity, recreation, so as not to be insulted, dapat berkumpul, prevent riots, in order to avoid drugs, trap a naughty friend (Patmonodewo, 2000:17). Through play activities provided by the child researcher will learn in the community by communicating with his friends, learn to respect to take turns waiting for your turn to play, learn to obey the rules of the game that the researcher has set in the game, togetherness and cooperation in playing games.

\section{F. Moral Standards}

Playing can also be a moral standard which means that through playing can be seen both the bad attitudes or behavior of children when playing. In children's play activities, they are free to express all their abilities freely in terms of attitude, behavior or speech, so that children who have a habit of behaving well or bad will appear in the play activity (Moeslichatoen, 1999:32). in playing activities in each of the culprit also required to have honesty, get good cooperation, sportive, subject to the rules of the game that have been outlined. With the provisions that must be obeyed in playing activities, then indirectly the regulations carried out in play activities will be embedded in the child (Nurhayati Simatupang. 2005). When the child performs game activities given by the researcher, children apply sportsmanship by alternating regularly, do good cooperation, and follow all the rules of the game that the researcher has submitted, although there are some children who behave poorly, like taking the ball forcibly from another friend, and there are also those who issued words that should not be spoken, so the researcher gives advice and direction to students who carry out the action so that they know that it's wrong and then stop to do it.

In accordance with the results of interviews and observations that the researchers obtained in the field that the students who were in Padang Perwari Special School were initially shy to do the game activities provided by the researchers, after students do and are given support from their environment, make students excited and want to try the game again. The problem of selfconfidence in children must be handled or addressed quickly so as not to damage other social aspects that will adversely affect the child's soul. Actually humans have their advantages and disadvantages, with the method given, researchers must see the advantages and disadvantages of students in Padang Perwari Special School to conduct an effective learning process so that students are able to capture what the researchers convey. 


\section{CONCLUSION}

From the results and discussion above the researcher concludes that playing is a physical activity that is carried out in earnest and voluntary and fun that is often done by most children. The impact of playing is not only on the physical aspects but also on the social aspects, melalui permainan edukatif dalam pendidikan jasmani yang diberikan peneliti, the child is able to build his confidence in interacting, communicate, cooperation, and children do not know the shortcomings, but also the strengths that exist in children,.

\section{REFERENCES}

Abdullah, Nandiyah. 2013. Mengenal Anak Berkebutuhan Khusus. Klaten: Fakultas Psikologi UNWIDHA Klaten Magistra No. 86 Th. XXV Desember 2013 1 ISSN 0215-9511.

Adywibowo, Inge Pudjiastuti. 2010. Memperkuat Kepercayaan Diri Anak melalui Percakapan Referensial. Jakarta: badan pendidikan Kristen PENABUR (BPK PENABUR). Jurnal Pendidikan Penabur - No.15/Tahun ke-9/Desember 2010. ISSN: 1412-2588.

Al-usqhari, yusuf. 2005. Percaya Diri, Pasti! Diterjemahkan Abdul Hayyie AlKattani, Noor Cholis Hamzain. Jakarta: Gema Insani Press.

Bohlin, E. Karen., Deborah Farmer, \& Kevin Ryan, 2001. Building Character inSchool Resource Guide. San Fransisco: Jossey Bass.

Bungin, Burhan. (2003). Analisis Data Penelitian Kualitatif. Jakarta: PT Raja Grafindo Persada.

Efendi, M., 2006, Pengantar Psikopedagogik Anak Berkelainan, Jakarta, Bumi Aksara.

Elmubarok, Z. (2008). Membumikan Pendidikan Nilai. Bandung: Alfabeta.

Fatah Yasin Al Irsyadi dan Yusuf Sulistyo Nugroho. 2015. Game Edukasi Pengenalan Anggota Tubuh Dan Pengenalan Angka Untuk Anak Berkebutuhan Khusus (Abk) Tunagrahita Berbasis Kinect. Surakarta: Universitas Muhammadiyah Surakarta Prosiding SNATIF Ke -2 Tahun 2015 ISBN: 978-6021180-21-1.

Hidayatullah, Furqon. 2010. Pendidikan Karakter Membangun Peradaban Bangsa. Surakarta: Yuma Pustaka.

Horn, Thelma S. 2008. Advances In Sport Psychologis. USA: Human kinetics. 
Lautser, P. 2003. Tes kepribadian (alih bahasa: D.H. Gulo). Jakarta: PT. Bumi Aksara.

Lickona, Thomas. 1991. Educating for Character: How Our School Can Teach Respect and Responsibility. New York: Bantam Books.

Maftuhatin, Lilik. 2014. Evaluasi Pembelajaran Anak Berkebutuhan Khusus (Abk) Di Kelas Inklusif Di Sd Plus Darul Ulum Jombang. Jombang: Universitas Pesantren Tinggi Darul Ulum Jombang.

Moeslichatoen. (1999). Metode Pengajaran di Taman Kanak-kanak, Jakarta : PT.Rineka Cipta.

Noviyanti, Mery. 2011. Pengaruh Motivasi Dan Keterampilan Berkomunikasi Terhadap Prestasi Belajar Mahasiswa Pada Tutorial Online Berbasis Pendekatan Kontekstual Pada Matakuliah Statistika Pendidikan. Jakarta: FKIP-UT. Volume 12.

Patmonodewo.(2000). Pendidikan Anak Prasekolah, Jakarta: Depdikbud dan Penerbit PT Rineka Cipta.

Patton, M. Q. (2002). Qualitative Researchand Evaluation Methods (3rded.). Thousand Oaks, CA: Sage Publications, Inc.

Prastowo, Gurit dan Syam, Abdul Rachman. 2014. Pengaruh Metode Pembelajaran Part Practice Terhadap Hasil Belajar Shooting Bola Basket (Studi Pada Siswa Kelas Xi-Ips Sma Negeri 1 Cerme). Surabaya: Universitas Negeri Surabaya Jurnal Pendidikan Olahraga dan Kesehatan Volume 02 Nomor 03 Tahun 2014, 747 - 749 ISSN : 2338-798X.

Simatupang, Nurhayati. 2005. Bermain Sebagai Upaya Dini Menanamkan Aspek Sosial Bagi Siswa Sekolah Dasar. Medan: Universitas Negeri Medan.

Sukintaka. (1998). Teori Bermain untuk Pendidkan Jasmani. Yogyakarta: FPOK IKIP.

Tedjasaputra, Mayke S. (2001). Bermain, mainan dan Permainan. Jakarta : Grasindo.

Utama, Bandi. 2011. Pembentukan Karakter Anak Melalui Aktivitas Bermain Dalam Pendidikan Jasmani. Yogyakarta: Universitas Negeri Yogyakarta.

Utari, Yuniar Indah dan Indahwati, Nanik. 2015. Upaya Meningkatkan Gerak Dasar Lokomotor Anak Tunagrahita Ringan Melalui Permainan Tradisional (Pada Siswa-Siswi Sekolah Dasar Luar Biasa Tunas Mulya Surabaya). Surabaya: Universitas Negeri Surabaya Jurnal Pendidikan Olahraga dan Kesehatan Volume 03 Nomor 02 Tahun 2015, 279 - 282 ISSN : 2338-798X. 